\title{
Multi-scale environmental filters and niche partitioning govern the distributions of riparian vegetation guilds
}

\author{
Nate Hough-Snee, ${ }^{1} \uparrow$ Brian G. Laub, ${ }^{1}$ David M. Merritt ${ }^{2,3}$ A. Lexine Long ${ }^{1,4}{ }^{1,}$ loyd L. Nackley, ${ }^{5}$ \\ BRETT B. ROPER, ${ }^{1,6}$ AND JOSEPH M. WHEATON ${ }^{1}$ \\ ${ }^{1}$ Department of Watershed Sciences and Ecology Center, Utah State University, Logan, Utah 84322-5210 USA \\ ${ }^{2}$ USDA Forest Service, National Stream and Aquatic Ecology Center, \\ Natural Resource Research Center, Fort Collins, Colorado 80526 USA \\ ${ }^{3}$ Graduate Degree Program in Ecology, Colorado State University, Fort Collins, Colorado 80526 USA \\ ${ }^{4}$ United States Geological Survey, Southwest Biological Science Center, Flagstaff, Arizona 86011 USA \\ ${ }^{5}$ University of California Davis, Department of Plant Sciences, Davis, California 95616 USA \\ ${ }^{6}$ USDA Forest Service, National Stream and Aquatic Ecology Center, Forest Sciences Laboratory, Logan, Utah 84321 USA
}

Citation: Hough-Snee, N., B. G. Laub, D. M. Merritt, A. L. Long, L. L. Nackley, B. B. Roper, and J. M. Wheaton. 2015. Multi-scale environmental filters and niche partitioning govern the distributions of riparian vegetation guilds. Ecosphere 6(10):173. http://dx.doi.org/10.1890/ES15-00064.1

\begin{abstract}
Across landscapes, riparian plant communities assemble under varying levels of disturbance, environmental stress, and resource availability, leading to the development of distinct riparian life-history guilds over evolutionary timescales. Identifying the environmental filters that exert selective pressures on specific riparian vegetation guilds is a critical step in setting baseline expectations for how riparian vegetation may respond to environmental conditions anticipated under future global change scenarios. In this study, we ask: (1) What riparian plant guilds exist across the interior Columbia and upper Missouri River basins? (2) What environmental filters shape riparian guild distributions? (3) How does resource partitioning among guilds influence guild distributions and co-occurrence? Woody species composition was measured at 703 stream reaches and each species' morphological and functional attributes were extracted from a database in four categories: (1) life form, (2) persistence and growth, (3) reproduction, and (4) resource use. We clustered species into guilds by morphological characteristics and attributes related to environmental tolerances, modeling these guilds' distributions as a function of environmental filtersregional climate, watershed hydrogeomorphic characteristics, and stream channel form-and guild coexistence. We identified five guilds: (1) a tall, deeply rooted, long-lived, evergreen tree guild, (2) a xeric, disturbance tolerant shrub guild, (3) a hydrophytic, thicket-forming shrub guild, (4) a low-statured, shadetolerant, understory shrub guild, and (5) a flood tolerant, mesoriparian shrub guild. Guilds were most strongly discriminated by species' rooting depth, canopy height and potential to resprout and grow following biomass-removing disturbance (e.g., flooding, fire). Hydro-climatic variables, including precipitation, watershed area, water table depth, and channel form attributes reflective of hydrologic regime, were predictors of guilds whose life history strategies had affinity or aversion to flooding, drought, and fluvial disturbance. Biotic interactions excluded guilds with divergent life history strategies and/or allowed for the co-occurrence of guilds that partition resources differently in the same environment. We conclude that the riparian guild framework provides insight into how disturbance and bioclimatic gradients shape riparian functional plant diversity across heterogeneous landscapes. Multiple environmental filters should be considered when the riparian response guild framework is to be used as a decisionsupport tool framework across large spatial extents.
\end{abstract}

Key words: climate change; community assembly; functional diversity; landscape ecology; life history strategy; riparian disturbance-response guilds; riparian flow-response guilds; riparian management.

Received 19 April 2015; revised 8 June 2015; accepted 9 June 2015; published 12 October 2015. Corresponding Editor: R. Sponseller. 
Copyright: ( 12015 Hough-Snee et al. This is an open-access article distributed under the terms of the Creative Commons Attribution License, which permits unrestricted use, distribution, and reproduction in any medium, provided the original author and source are credited. http://creativecommons.org/licenses/by/3.0/

† E-mail: nate@natehough-snee.org

\section{INTRODUCTION}

Riparian zones are globally threatened ecosystems due to widespread hydrologic alteration, watershed degradation, and the introduction of novel disturbance regimes and biota (Patten 1998, Shafroth et al. 2002, Stromberg et al. 2012, Dalldorf et al. 2013). A consequence of riparian vegetation degradation is the decline of vegetation-mediated ecosystem processes including allocthonous energy subsidies to aquatic ecosystems (Delong and Brusven 1994), contribution of large wood to stream channels (Hough-Snee et al. 2014a), temperature regulation by mature overstory vegetation (Pollock et al. 2009), and valuable terrestrial wildlife habitat (Merritt and Bateman 2012). Accordingly, any disturbance or ecosystem process that alters the composition or structure of riparian vegetation is also likely to alter channel form (Gurnell 2014) and riparian (Scott et al. 2003, Cooke and Zack 2008) and aquatic habitats (Herbst et al. 2012). The interrelationships between riparia, hydrogeomorphic processes, and ecosystem services pose a fundamental question in watershed management: what environmental factors are most responsible for governing the characteristics of riparian vegetation across landscapes? Additionally, how can these factors be managed to sustain the functions and habitat values of riparian ecosystems?

To address these questions, ecologists have suggested that by aggregating individual species into groups based on common life history strategies (Box 1) broad inference can be made about the environmental drivers of riparian plant diversity and used to predict ecosystem change (Merritt et al. 2009, 2010). This approach to riparian plant community assembly, the determination of riparian vegetation "flow-response guilds" (Merritt et al. 2010), provides a framework to identify how functional vegetation guilds assemble across environmental gradients that filter species and life history strategies from biological communities. Environmental filtering, in its most simple form, assumes that as environmental conditions change, specific life history strategies and traits will be selected for at a given location, leading to the assembly of communities with morphological and physiological tolerances suited to a given environment (Keddy 1992, Díaz et al. 1998). When the dominant environmental filters that shape riparian biodiversity are known, then riparian guilds can be probabilistically modeled to predict ecosystem change as environmental filters shift (Merritt et al. 2009). While many environmental filters shape riparian plant communities (HoughSnee et al. 2014b), the most commonly studied environmental drivers of riparian vegetation are hydrology and fluvial processes in large, alluvial rivers (Merritt and Cooper 2000, Naiman et al. 2000, Stella et al. 2013).

Not coincidentally, riparian plant communities have commonly been characterized based on relationships between species composition and the magnitude, duration, and timing of stream flow or surrogate flow measurements like stream order (Ekness and Randhir 2007, Stella and Battles 2010, Viers et al. 2012) or hydrologic and substrate characteristics of fluvial surfaces (Hupp and Osterkamp 1996, Bendix and Hupp 2000). Indeed, within large rivers, hydrogeomorphic processes that dictate intra- and interannual shifts in overbank flooding, erosion, deposition, and hydrologic recession play a strong role in shaping vegetation functional diversity, including guilds (Shafroth et al. 2002, Katz et al. 2009). The historic focus on riparian plant diversity in large, alluvial rivers has left much to be learned about how environmental processes shape riparian ecosystems, especially in unregulated, loworder streams.

While headwaters make up disproportionate amounts of stream area within watersheds (Lowe and Likens 2005), the environmental filters that control riparian plant functional diversity in loworder streams have rarely been elucidated at broad spatial scales (Hough-Snee et al. 2014b). Many riparian ecosystems, especially those along small streams, can be linked to landscape to local-scale processes such as climate, land management, and fluvial disturbance (Richardson 


\section{Box 1 \\ Glossary of Terms Used to Describe Guilds}

Riparian guild: (noun) A group of species with a common life history strategy based on species morphological and/or functional traits. This common life history strategy allows a guild to occupy a unique niche within a riparian environment (Merritt et al. 2009, 2010). For example, riparian vegetation-flow response guilds (sensu Merritt et al. 2009, 2010) are organized into guilds based on species' traits that respond predominantly to hydrologic and hydrogeomorphic variability.

Riparian guilding: (verb) The process of quantitatively identifying groups of species with shared life history strategies through the clustering of species by their functional and morphological traits or attributes (Merritt et al. 2009, 2010).

Functional trait: A quantitatively measured plant trait that is used to describe a species' or individual's physiological performance, e.g., stem water potential, wood density, photosynthesis, seed size (Keddy 1992, Grime 2001).

Functional or morphological attribute: Any categorical or semi-quantitative estimate used to describe a plant species' environmental tolerances or general morphology. These can be ordinal or categorical, e.g., flooding tolerance, flower timing, rhizomatous vs. taproot rooting strategies, etc.

Life history strategy: a species' or guild's life history strategy is comprised of various investments in individuals' persistence and growth, survival, and reproduction (sensu Grime 1977). Species' measured functional traits, or categorized/estimated functional or morphological attributes are all used to describe species life history strategies. Here we describe species life history strategies using life form, persistence and growth, reproduction, and resource use.

Life history stages: thresholds between component functional traits or attributes (life history strategies) within or between species or guilds (sensu Huston and Smith 1987). We relate these thresholds to four coarse categories: life form, persistence and growth, reproduction, and resource use. For example, mature cottonwood trees have different physical habitat and physiological requirements for survival and reproduction than younger, smaller, reproductively immature seedlings of the same species.

Life form: pertains to the dominant aboveground and belowground strategies employed by a species. Life form can be tied to longevity through direct age estimates or categorical variables that correspond to major differences in dominant life history strategies, e.g., perennial vs. annual, forb vs. shrub, etc.

Persistence and growth: pertains to the potential for a species to persist, and grow in the riparian environment where environmental disturbance and resource gradients provide diverse conditions that species/guilds must survive within.

Reproduction: pertains to the strategies by which species reproduce and the relative timing of these strategies in response to predominantly fluvial disturbance and fluctuating hydrologic regimes.

Resource use: pertains to the potential of each species or guild to acquire limiting resources, namely water and nitrogen as used here.

and Danehy 2007, Dunn et al. 2011, Hough-Snee et al. 2014b) and biotic interactions (Whigham et al. 2012). Riparian plant communities assemble through both biotic and abiotic environmental filters that limit which species and functional traits can occur at a given location within a stream network (Díaz et al. 1998). While riparian environmental filters may occur at multiple spatial and temporal scales within a given environment (e.g., process domains; Montgomery 1999), filtering can select for comparable sets of traits or guilds with shared life history 
strategies, regardless of the dominant processes at work. These filters, whether they originate from stream or upland processes, exert selective pressures on traits that allow species to persist and reproduce in a given environment.

Identifying trait-based plant assemblages provides a novel approach for assessing plant functional diversity where numerous species with similar realized niches and corresponding life history strategies may occur (Grime 1977, Merritt et al. 2010). Riparian guilding (Merritt et al. 2010), allows for the identification of groups of species with shared functional traits, morphological characteristics, or environmental preferences that correspond to distinct life history strategies. These guilds may respond to individual or multiple environmental filters, including water availability and the frequency and magnitude of fluvial disturbance (Merritt et al. 2010), depending on the attributes used in guilding species (Catford and Jansson 2014). Within riparian ecosystems, guild-based approaches have been used to identify how functional riparian vegetation assemblages respond to flow regulation (Bejarano et al. 2012, 2013). However, riparian guild determination, or "riparian guilding," may also provide insights into the broad environmental filters that shape riparian plant functional diversity across landscapes. By assessing riparian plant diversity based on attributes representative of shared life history strategies rather than individual species, theories may be made about what filters drive different life history strategies across regions with large species pools.

Riparian guilding provides a powerful tool for explaining how different niches are occupied by specific life history strategies across landscapes. While environmental filtering may broadly explain how species, traits, and assemblages occupy a stream reach, niche partitioning within communities may be based on the complementarity or divergence of guilds' functional traits and life history strategies, enabling multiple trait syndromes to coexist. That is, multiple life history strategies and guilds may co-exist in the same community due to their different strategies for tolerating environmental stress, responding to disturbance, and acquiring nutrients and water (niche partitioning; Grime 1977, Catford and Jansson 2014).

To investigate relationships between riparian functional plant diversity and environmental filtering, we pose two sets of questions in this paper:

1. Can meaningful riparian woody plant guilds be identified based on species' shared morphological and life history attributes or are traits distributed along a continuum of individualistic attributes? If meaningful guilds can be identified, what are the functional differences between guilds and the nature of each guild's dominant life history strategies?

2. How do environmental filters and the presence and absence of complementary guilds shape the distribution of individual riparian guilds across landscapes? How do environmental filters shape guild assemblages, the combination of guilds present at a given site, across landscapes?

\section{Methods}

\section{Study sites}

We selected 703 low-order stream reaches within the interior Columbia and upper Missouri River basins (Fig. 1) for inclusion in the study. These reaches were sampled under a spatially balanced, probabilistic sampling design (Kershner et al. 2004). All reaches were low-gradient (average $<2 \%$ ) and occur within USGS 6th order hydrologic unit code sub-watersheds with $>50 \%$ federal ownership upstream of the sampled reach. Study reaches are managed by the U.S. Bureau of Land Management (BLM) or Forest Service (USFS) and occur across the physical and climatic gradients representative of the interior Columbia and upper Missouri River basins.

\section{Vegetation field data}

Riparian vegetation was sampled during the growing season at base flow conditions (JuneSeptember). Greenline vegetation data were collected in $42-50$ evenly spaced quadrats $(50 \times$ $20 \mathrm{~cm}$ ) per reach, based on reach length and bankfull width (PIBO EM 2012a). The greenline is the point at which the first rooted perennial vegetation is present along a stream (Winward 2000, PIBO EM 2012a) and is located on flat, floodplain-like or depositional features at or near bankfull stage. Vascular plants were measured in 


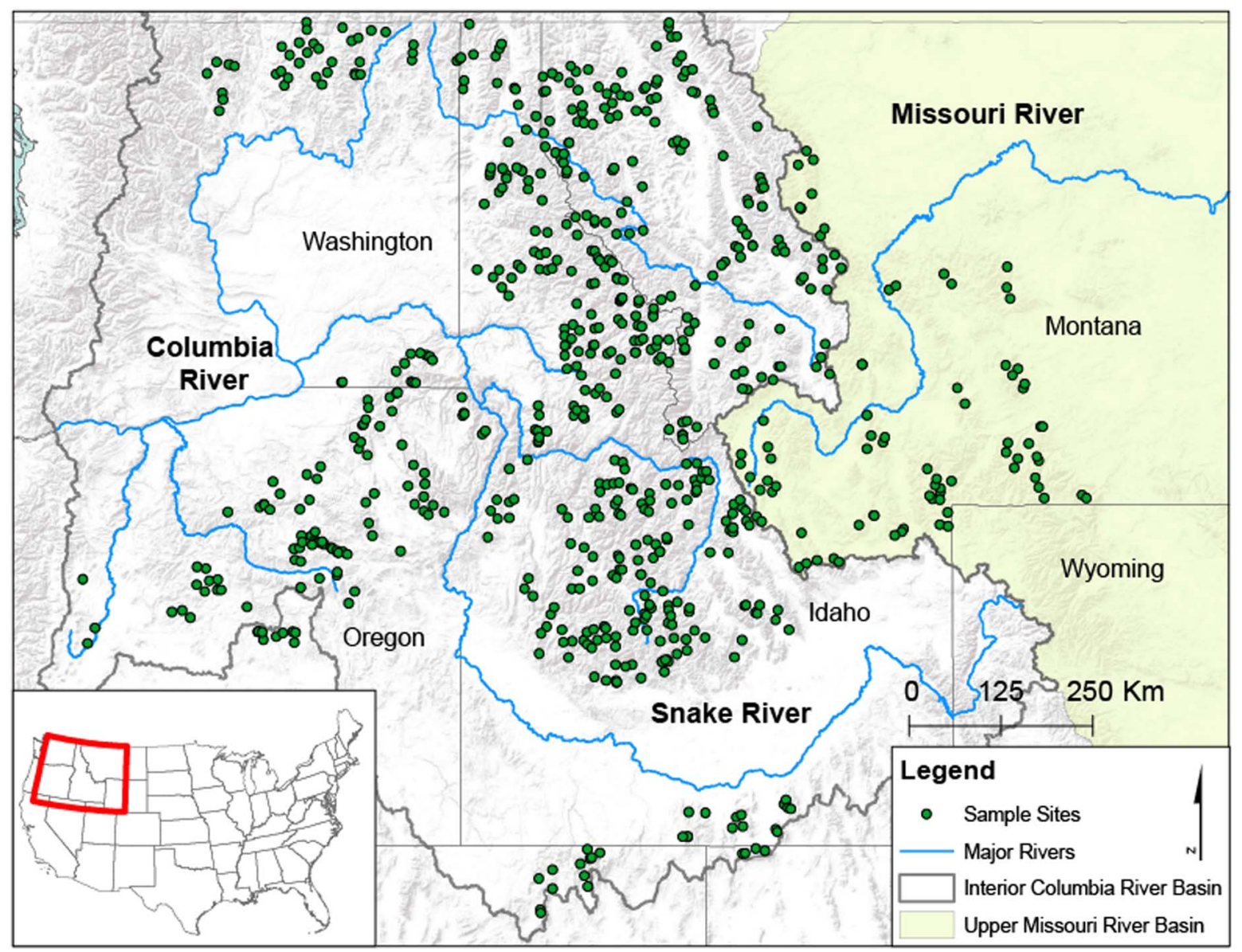

Fig. 1. The 703 study reaches in the Missouri and Columbia River basins where riparian vegetation and stream attributes were sampled. All reaches occurred on low-order streams (1st-6th order) in watersheds under predominantly federal ownership.

a lower vegetation layer $(<1 \mathrm{~m}$ in height) and an upper woody species layer ( $>1 \mathrm{~m}$ in height). If a species was observed in either vegetation layer, then it was classified as present at a site, otherwise it was classified as absent.

\section{Riparian plant attributes for defining life history strategy and guilds}

We identified functional groups by allocating species to groups based on life history strategies as a product of their shared functional and morphological attributes, selecting attributes based on their importance in maintaining individual plants and populations within a riparian environment along a typical, low-order stream. Smaller, wadeable streams are exposed to multiple stressors from fluvial (overbank flooding, erosion, deposition, etc.) and terrestrial processes (wildfire, grazing, forest fragmentation, etc.) as well as climatic variability across landscapes. Accordingly, the plant attributes we selected for guilding aligned with multiple environmental filters across the riparian environment and study landscape (Table 1). We used the USDA Plants database (USDA NRCS 2010) to identify functional attributes that pertained to each plant species' life-form, persistence and growth, disturbance and stress responses, resource use, and reproductive strategy (Table 1). For simplified description, each attribute was allocated to a primary life history stage based on that attribute's dominant role in defining a species general life form, survival and growth, resource use, or reproduction in the riparian environment (Table 
Table 1. Initial functional and morphological attributes used in the determination of riparian functional guilds. Species' functional and morphological attribute levels and values were acquired from the USDA PLANTS database (USDA NRCS 2010) except for live-staking, which was acquired from Burgdorf (2007). Each attribute is broken into one of four coarse life history stages: life form, persistence and growth, reproduction, and resource use. The levels of each attribute are listed in Appendix A and illustrated in Fig. 3.

\begin{tabular}{|c|c|c|c|}
\hline $\begin{array}{l}\text { Species' functional and } \\
\text { morphological attributes }\end{array}$ & $\begin{array}{l}\text { Variable } \\
\text { type }\end{array}$ & $\begin{array}{l}\text { Dominant life } \\
\text { history category }\end{array}$ & $\begin{array}{l}\text { Plant-environment associations in the } \\
\text { riparian environment }\end{array}$ \\
\hline Growth form & categorical & life form & $\begin{array}{l}\text { overbank flooding response, light and } \\
\text { water acquisition within canopies }\end{array}$ \\
\hline Lifespan & categorical & life form & temporal response to flooding, drying, etc. \\
\hline Adapted to coarse textured soils & categorical & persistence and growth & $\begin{array}{l}\text { seed dispersal, germination and plant } \\
\text { water relations in alluvial substrate }\end{array}$ \\
\hline Adapted to fine textured soils & categorical & persistence and growth & $\begin{array}{l}\text { seed dispersal, germination and plant } \\
\text { water relations in alluvial substrate }\end{array}$ \\
\hline Adapted to medium textured soils & categorical & persistence and growth & $\begin{array}{l}\text { seed dispersal, germination and plant } \\
\text { water relations in alluvial substrate }\end{array}$ \\
\hline Anaerobic tolerance & categorical & persistence and growth & $\begin{array}{l}\text { depth, duration and timing of soil } \\
\text { saturation from overbank flooding }\end{array}$ \\
\hline Drought tolerance & categorical & persistence and growth & $\begin{array}{l}\text { response to seasonal soil drying and } \\
\text { moisture deficit }\end{array}$ \\
\hline Fire tolerance & categorical & persistence and growth & $\begin{array}{l}\text { ability for stems to resprout, and/or seeds } \\
\text { to disperse or germinate following fire }\end{array}$ \\
\hline Growth rate & categorical & persistence and growth & $\begin{array}{l}\text { biomass production from photosynthetic } \\
\text { carbon gains minus respiration costs }\end{array}$ \\
\hline $\mathrm{C}: \mathrm{N}$ ratio & categorical & persistence and growth & $\begin{array}{l}\text { leaf-level photosynthesis, tissue } \\
\text { construction and maintenance from soil } \\
\text { nutrition and atmospheric light, } \mathrm{h}_{2} \mathrm{O}, \mathrm{CO}_{2}\end{array}$ \\
\hline Height at maturity & continuous & persistence and growth & $\begin{array}{l}\text { ability to acquire atmospheric light and } \mathrm{CO}_{2} \\
\text { response to flooding and fluvial shear } \\
\text { stress }\end{array}$ \\
\hline Leaf retention & categorical & persistence and growth & $\begin{array}{l}\text { maintenance and construction costs of } \\
\text { photosynthetic tissues }\end{array}$ \\
\hline Resprout ability & categorical & persistence and growth & $\begin{array}{l}\text { response to flooding and fluvial shear } \\
\text { stress, fire, and herbivory }\end{array}$ \\
\hline Shade tolerance & categorical & persistence and growth & $\begin{array}{l}\text { capability to account for cellular respiration } \\
\text { costs and gain carbon in reduced light } \\
\text { environments like forest understories }\end{array}$ \\
\hline Vegetative spread rate & categorical & persistence and growth & $\begin{array}{l}\text { ability to reproduce and grow rapidly } \\
\text { following disturbance }\end{array}$ \\
\hline Bloom period & categorical & reproduction & $\begin{array}{l}\text { flowering timing in response to } \\
\text { environmental cues (flooding, climate, } \\
\text { etc.) }\end{array}$ \\
\hline Fruit/seed abundance & categorical & reproduction & $\begin{array}{l}\text { the amount of seed corresponds to the } \\
\text { dispersal and reproductive strategy of a } \\
\text { species during flood recession }\end{array}$ \\
\hline Fruit/seed period begin & categorical & reproduction & $\begin{array}{l}\text { timing of seed set relative to freshet and } \\
\text { peak floods in snow-melt dominated } \\
\text { streams }\end{array}$ \\
\hline Fruit/seed persistence & categorical & reproduction & $\begin{array}{l}\text { how long propagules remain viable and } \\
\text { persist following dispersal }\end{array}$ \\
\hline Live-staking & categorical & reproduction & $\begin{array}{l}\text { the capability of a species to adventitiously } \\
\text { root when placed into an anaerobic soil } \\
\text { environment }\end{array}$ \\
\hline Moisture use & categorical & resource use & $\begin{array}{l}\text { required moisture to support transpiration } \\
\text { and maintain whole plant water balance }\end{array}$ \\
\hline Root depth & continuous & resource use & $\begin{array}{l}\text { potential for an individual to acquire soil } \\
\text { resources: moisture, nutrients, etc. }\end{array}$ \\
\hline Nitrogen fixation & categorical & resource use & $\begin{array}{l}\text { symbiotic relationships with atmospheric } \\
\text { nitrogen-fixing bacteria in plant roots } \\
\text { allows nitrogen acquisition in nutrient- } \\
\text { poor alluvial substrates }\end{array}$ \\
\hline
\end{tabular}

1). Generally, plant traits may be categorized as biological traits measured on individual plants, or ecological traits that reflect species' responses to the environment. The ecological attributes used here may be thought of as surrogates for, or integrators of, traits that reflect environmental adaptation.

For example, adaptation to different soil 
textures and sizes illustrates the capacity for a plant to persist and grow in an environment where interannual differences in deposition and erosion may deposit a range of sediment size classes in the same location. This same functional attribute is also representative of a species' reproduction potential because deposited sediment provides sites where hydrochorous propagules (seeds, sprigs, etc.) collect and germinate following spring flooding. Moisture use, drought tolerance, and anaerobic soil tolerance are all tied to species' abilities to germinate, persist, photosynthesize, and grow amid intrannual and interannual hydrologic variability. The timing and duration of flowering, seed set and seed dormancy (persistence) are all tied to a species' reproductive life history strategy in riparian areas, namely the timing of hydrochorous and post-flood seed dispersal (Merritt and Wohl 2006).

We use the term morphological or functional "attribute" as opposed to "trait," because traits are defined as empirically measured physiological and morphological parameters that change in response to the physical environment (Box 1; Mcgill et al. 2006), whereas many of our species attributes were categorizations or on an ordinal scale and not empirical measurements. It is worth noting that of the small number of attributes selected for guild analysis, many often covary or have trade-offs with other traits. A limited number of attributes (or when available, measured traits) may be used in such guild analyses, providing the advantage that a parsimonious set of traits may actually represent a family of traits (Duckworth et al. 2000). For example, wood density is easy to measure yet represents a complex set of physiological traits that are strongly correlated with water use efficiency in plants (Reich 2014).

\section{Environmental metrics}

Stream gradient, bankfull width, bank stability, channel sinuosity, bank angle, median particle size, wood frequency, wetted width-depth ratio, residual pool depth, hydraulic radius, and percent undercut banks were field measured at each reach using standardized protocols (Table 2; PIBO EM 2012b). We identified a 30m buffer surrounding each stream in GIS and calculated the proportion of each buffer polygon that was grazed by livestock in the last 30-years using USFS grazing allotment data. Because forest patches serve as corridors for propagule dispersal and tree canopies shape understory light and humidity, we identified the proportion of each watershed and reach covered by overstory forest vegetation using LANDFIRE (USGS 2012). We also used LANDFIRE data to estimate the proportion of each watershed that had burned between 1997 and 2007. We calculated road density $\left(\mathrm{km} / \mathrm{km}^{2}\right)$ within each buffer and watershed because roads serve as plant dispersal vectors and alter local hydrology. We used $10 \mathrm{~m}$ digital elevation models to define watershed boundaries and calculate watershed area, stream density and the average slope of the watershed and buffer surrounding each reach. An erosivity index - a unitless, continuous measure of the uniaxial compressive strength of lithology types-was calculated to estimate the relative erosion potential at each reach (Cao et al. 2007). Average soil thickness and depth to the seasonal high water table, indicators of hydric soils, were estimated at each reach (NRCS 2012). All landscape and watershed-scale filters were summarized for the watershed area upstream of each reach (Table 2).

\section{Riparian guild identification}

We identified riparian guilds by clustering species into groups based on their combinations of morphological and physical attributes (Table 1). We calculated a distance matrix of species and species' attributes using Gower's distance (Gower and Legendre 1986), which scales variables between 0 and 1 and allows for the use of continuous and ordinal variables. We clustered species based on this distance matrix using Ward's method and examined cluster results for three to ten guilds, settling on a five-guild (cluster) solution. We visualized the resulting guilds, and the attributes that differentiated them, using a three-dimensional principal coordinate analysis (PCoA). Guild fidelity was tested using permuational analysis of variance (PERMANOVA) models (Anderson 2001) with the null hypothesis that the attribute composition of each species guild did not differ. Species' life history strategy attributes were correlated to the ordination solution using multiple regression and plotted to illustrate relationships between 
Table 2. Summaries (mean, standard deviation, minimum and maximum) of environmental filters used to predict riparian guild presence and absence. Buffer variables were summarized within a 30-m buffer of the stream reach, while watershed and landscape variables were summarized for the upstream area above each fieldsampled reach. Stream variables were field-sampled at individual reaches.

\begin{tabular}{|c|c|c|c|c|c|c|}
\hline Environmental scale and variable & Abbreviation in figures & Data source & Mean & SDD & Min & Max \\
\hline \multicolumn{7}{|l|}{ Landscape } \\
\hline Elevation $(\mathrm{m})$ & MinElev & USGS NED & 1429.32 & 455.89 & 186.00 & 2714.00 \\
\hline 30 -year average precipitation $(\mathrm{m})$ & AvgPrecip & PRISM & 0.93 & 0.32 & 0.27 & 1.86 \\
\hline 30 -year average temperature $\left({ }^{\circ} \mathrm{C}\right)$ & AvgTemp & PRISM & 3.74 & 1.93 & -2.50 & 11.87 \\
\hline Annual precipitation $(\mathrm{m})$ & AnnPrecip & PRISM & 0.91 & 0.34 & 0.25 & 2.10 \\
\hline \multicolumn{7}{|l|}{ Watershed disturbance and hydrology } \\
\hline Watershed area $\left(\mathrm{km}^{2}\right)$ & Watershed Area & USGS NED & 45.97 & 73.59 & 0.57 & 886.82 \\
\hline Watershed burned (\%) & Watershed Burned & LANDFIRE & 10.21 & 25.04 & 0.00 & 100.0 \\
\hline Average depth water table $(\mathrm{m})$ & AvgWater Table & NRCS & 1.15 & 0.28 & 0.36 & 1.52 \\
\hline Soil thickness (m) & AvgSoil Thick & NRCS & 1.78 & 0.11 & 0.77 & 1.82 \\
\hline \multicolumn{7}{|l|}{ Stream buffer $(30-\mathrm{m}$ riparian buffer) } \\
\hline Forested in buffer $(\%)$ & BufForested & LANDFIRE & 70.24 & 17.32 & 0.48 & 100.0 \\
\hline Grazing in buffer (\%) & BufGrazed & USFS/BLM & 49.34 & 47.06 & 0.00 & 100.0 \\
\hline Roads in buffer (\%) & BufRoads & USFS/BLM & 1.34 & 1.49 & 0.00 & 7.91 \\
\hline Buffer slope $\left(^{\circ}\right)$ & BufSlope & USGS NED & 34.03 & 11.09 & 3.00 & 64.95 \\
\hline \multicolumn{7}{|l|}{ Hydrogeomorphic (stream channel form) } \\
\hline Bank angle $\left(^{\circ}\right)$ & BankAngle & Field measured & 109.70 & 19.41 & 53.0 & 157.0 \\
\hline Stream gradient $(\%)$ & Gradient & Field measured & 1.97 & 1.20 & 0.01 & 8.64 \\
\hline Bankfull width (m) & BfWidth & Field measured & 6.62 & 3.75 & 0.78 & 23.67 \\
\hline Sinuosity $(\%)$ & Sinuosity & Field measured & 1.27 & 0.33 & 1.00 & 5.66 \\
\hline Hydraulic radius $(\mathrm{m})$ & Hydraulic Rad & Field measured & 0.41 & 0.14 & 0.08 & 1.00 \\
\hline Wetted width:depth ratio & WetWD Ratio & Field measured & 25.57 & 14.57 & 1.40 & 192.82 \\
\hline Undercut banks (\%) & Undercut Bank & Field measured & 32.93 & 17.34 & 0 & 95 \\
\hline
\end{tabular}

life history attributes and species within the ordination space ("envfit" function; vegan package in R statistical software; Oksanen et al. 2013). We determined guild presence by creating lists of woody species that occurred at each reach. If any species from a given guild was field identified at a reach, then that guild was categorized as present. The combined species list for all reaches was reduced to common woody species that occurred at $5 \%$ or more of reaches (McCune and Grace 2002).Guild presence was not weighted based on species abundance or frequency.

\section{Environmental drivers and riparian guild coexistence}

To identify relationships between guilds within each guild assemblage we performed non-metric multidimensional scaling (NMDS) on a matrix of guild presence and absence at each reach, using Euclidean distance. To identify relationships between guild assemblages and stream, watershed, buffer, and landscape-scale variables we correlated environmental filters to the final NMDS solution using multiple regression models. Environmental vectors were considered significant fits to the guild assemblages with an alpha of $P<0.05$.
A systematic approach was taken to model each guild's presence and absence across the study region. Generalized linear models were fitted for each guild using environmental attributes as predictors of guild presence and absence (binomial function; logit link; Table 2). Prior to model building we removed environmental variables with correlations $>|0.65|$ to avoid collinearity between predictors, retaining the variable with a stronger hypothesized relationship to plant persistence in riparian zones. We included interaction terms for variables with spatial codependence including bank angle and buffer slope, sinuosity and gradient, and bankfull width and wetted width to depth ratio. We used an iterative, systematic approach to compare models for each guild, removing variables and/or interaction terms with hypothesized weak relationships with guild presence to minimize the AIC and negative log-likelihood for each model. This approach maintained an information theoretic approach that retained key hydrologic and climatic variables that were thought to have strong, meaningful biological relationships with plant life history strategies (guilds) and their component plant attributes.

To further explore how guild distributions were 
Table 3. Riparian functional guilds identified based on clustering species morphological and physical attributes into common life history strategies. Guilds were given descriptive names and shorthand names for reference in the text. Descriptions broadly generalize each guild's environmental tolerances and attributes observed in the species within that guild.

\begin{tabular}{|c|c|c|}
\hline Guild name (Short name) & Guild description & Guild species \\
\hline $\begin{array}{l}\text { Long-lived, deeply-rooted, shade } \\
\text { tolerant, evergreen tree (Evergreen } \\
\text { tree guild; } n=7 \text { ) }\end{array}$ & $\begin{array}{l}\text { Evergreen, shade tolerant, overstory } \\
\text { conifer tree species; long life spans, } \\
\text { short-moderate growth rate, tall } \\
\text { stature, deep roots, high drought } \\
\text { tolerance, no asexual reproduction, } \\
\text { nitrogen fixing, or live-staking, high } \\
\text { seed abundance, short seed } \\
\text { persistence and low anaerobic } \\
\text { tolerance. }\end{array}$ & $\begin{array}{l}\text { Abies grandis, Abies lasiocarpa, Picea } \\
\text { engelmannii, Pinus contorta, Pinus } \\
\text { ponderosa, Pseudotsuga menziesii, } \\
\text { Thuja plicata }\end{array}$ \\
\hline $\begin{array}{l}\text { Rapidly growing, multi-stemmed, } \\
\text { rhizomatous and thicket-forming, } \\
\text { drought-plastic shrub guild (Upland } \\
\text { disturbance shrub guild; } n=9 \text { ) }\end{array}$ & $\begin{array}{l}\text { Deciduous, moderate lifespan, multiple } \\
\text { stem, thicket forming and } \\
\text { rhizomatous species; Poorly adapted } \\
\text { to fine textured soils, well adapted to } \\
\text { moderate-coarse soils; Variable } \\
\text { anaerobic tolerance, moderate } \\
\text { drought tolerance, moderate to rapid } \\
\text { growth rates and moderate-high seed } \\
\text { abundance and low seed persistence. }\end{array}$ & $\begin{array}{l}\text { Acer glabrum, Alnus viridis, Dasiphora } \\
\text { fructosa, Menziesia ferruginea, } \\
\text { Philadelphus lewisii, Ribes } \\
\text { hudsonianum, Salix exigua, Spiraea } \\
\text { douglasii, Vaccinium scoparium }\end{array}$ \\
\hline $\begin{array}{l}\text { Low-moderate stature, hydrophytic, } \\
\text { multi-stemmed thicket forming } \\
\text { shrubs (Mesic shrub guild; } n=9 \text { ) }\end{array}$ & $\begin{array}{l}\text { Deciduous, short-moderate lived, low to } \\
\text { moderate stature, multiple stem, } \\
\text { thicket-forming shrubs; moderate } \\
\text { shade tolerance, slow-moderate } \\
\text { vegetative spread rate; moderate root } \\
\text { depth, high fire tolerance, low- } \\
\text { moderate anaerobic tolerance, high } \\
\text { moisture use, medium-high C:N ratio, } \\
\text { variable seed abundance and low } \\
\text { seed persistence. }\end{array}$ & $\begin{array}{l}\text { Alnus incana, Betula occidentalis, Rosa } \\
\text { acicularis, Rosa nutkana, Rubus } \\
\text { parviflorus, Salix drummondiana, } \\
\text { Salix geyeriana, Salix lucida, } \\
\text { Vaccinium membranaceum }\end{array}$ \\
\hline $\begin{array}{l}\text { Medium-deeply rooted, vegetatively } \\
\text { reproducing, alluvial substrate } \\
\text { preferring shrubs and trees } \\
\text { (Mesoriparian shrub and tree guild; } n \\
=8 \text { ) }\end{array}$ & $\begin{array}{l}\text { Deciduous shrubs and trees with } \\
\text { moderate-high stature and moderate- } \\
\text { deep roots; Adapted to all soil } \\
\text { textures, low-moderate anaerobic } \\
\text { tolerance, low drought tolerance, } \\
\text { moderate-rapid growth rates, high } \\
\text { moisture use, high live-staking } \\
\text { potential, medium-high fire tolerance }\end{array}$ & $\begin{array}{l}\text { Amelanchier alnifolia, Cornus sericea, } \\
\text { Populus balsamifera, Salix bebbiana, } \\
\text { Salix boothii, Salix melanopsis, Salix } \\
\text { sitchensis, Salix wolfii }\end{array}$ \\
\hline $\begin{array}{l}\text { Short-statured, shade-tolerant, water } \\
\text { stress and flooding intolerant } \\
\text { understory shrubs (Understory shrub } \\
\text { guild; } n=9 \text { ) }\end{array}$ & $\begin{array}{l}\text { Low stature, shade-tolerant, slow- } \\
\text { spreading species with moderate } \\
\text { rooting depths. Medium-high fire } \\
\text { tolerance, generally adapted to } \\
\text { medium-textured soils, and lacking } \\
\text { drought and anaerobic tolerance. } \\
\text { Medium soil moisture use and C:N } \\
\text { ratio. }\end{array}$ & $\begin{array}{l}\text { Cornus canadensis, Lonicera } \\
\text { involucrata, Rhamnus alnifolia, Ribes } \\
\text { inerme, Ribes lacustre, Rosa woodsii, } \\
\text { Rubus idaeus, Spiraea betulifolia, } \\
\text { Symphoricarpos albus }\end{array}$ \\
\hline
\end{tabular}

related to co-occurring guilds and environmental filters, we built conditional inference (classification) trees for each guild from the variables retained in that guild's final generalized linear model (ctree function; party package; $\mathrm{R}$ statistical software; Hothorn et al. 2006). Conditional inference trees are a machine-learning method that can operate on mixed variable types and are well suited to modeling non-linear and nonadditive relationships common in trait or categorical morphological attribute data (De'ath and Fabricius 2000). Classification maximizes the heterogeneity between nodes based on the variable with the strongest association with the response variable. We assessed conditional inference tree performance by fitting our observed data to the model and used Cohen's Kappa statistic to see if each tree performed better than random at predicting guild presence and absence.

\section{RESULTS}

\section{Riparian guilds}

We identified five riparian guilds comprised of 


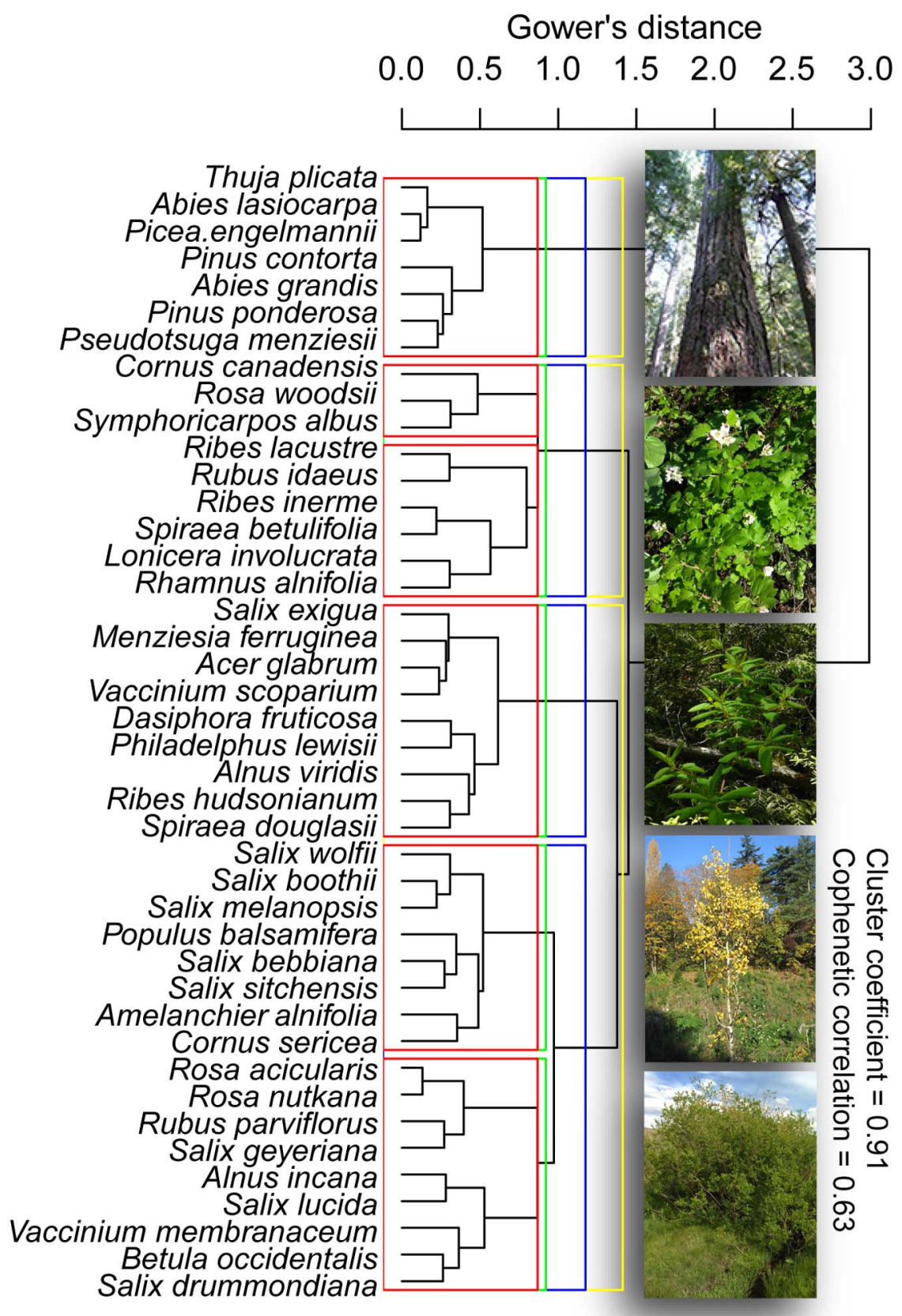

Fig. 2. The final dendrogram of species clustered by their traits using Gower's dissimilarity. Colored bands indicate sets of three (yellow), four (blue), five (green) and six (red) guilds that were examined post hoc. Five guilds were selected based on their observed ecological niches and guild fidelity using PERMANOVA: (ET) evergreen tree guild, (UD) upland disturbance guild, (MS) mesic shrub guild, (MR) mesoriparian shrub and tree guild, and (US) understory shrub guild. 
HOUGH-SNEE ET AL.

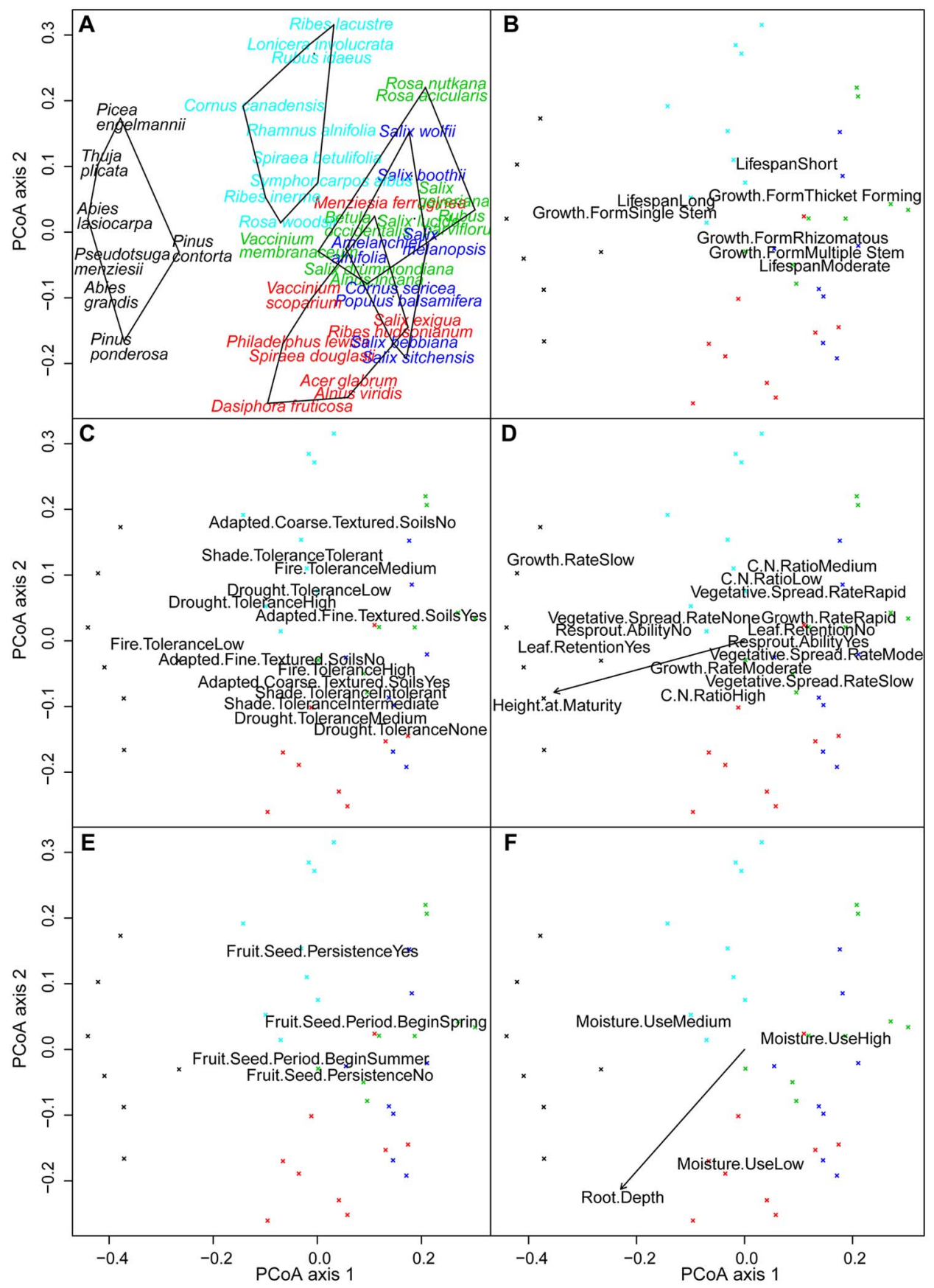

Fig. 3. Principal coordinates analysis (PCoA) of species clustered by traits into guilds showed that guilds have distinct life history strategies. Panel (A) shows the individual species by their guild membership: evergreen tree guild (black), upland disturbance guild (red), mesic shrub guild (green), mesoriparian shrub and tree guild (dark blue), and understory shrub guild (light blue). Continuous traits (vectors) and categorical traits (text only) significant at an alpha of $P<0.01$ are plotted over the PCoA solution by life form (B), persistence and growth (C and $D)$, reproduction $(E)$, and resource use $(F)$. Traits are shown in the PCoA ordination space over points that correspond to each species, colored by functional guild (A). The full suite of species and attributes used in guilding are described further in Tables 1 and 3. 


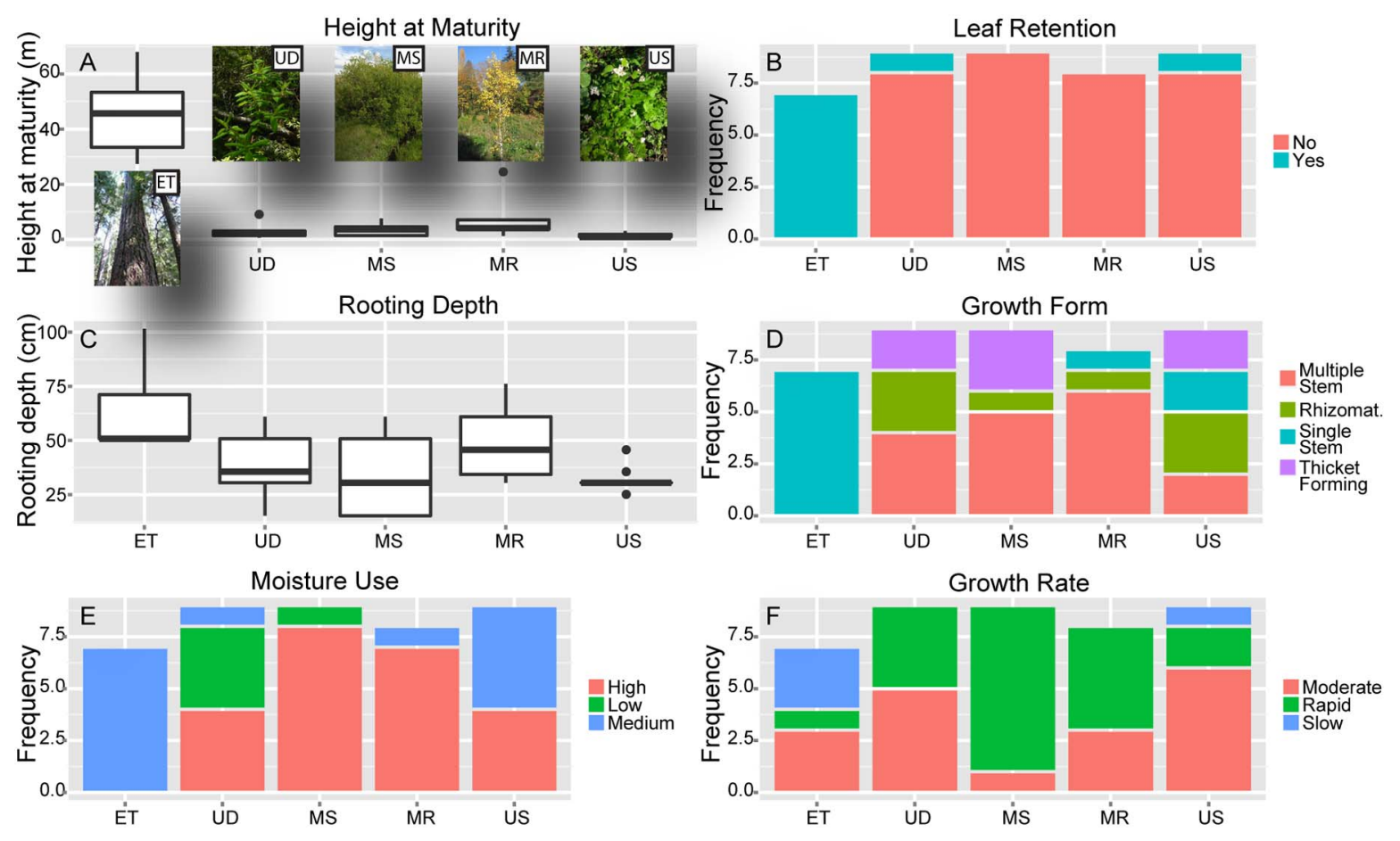

Fig. 4. Summaries of the six morphological and physical attributes most strongly correlated to the principal coordinates analysis of clustered species and guilds showed different life history strategies for each guild. Guilds along the horizontal axis are from left to right, (ET) evergreen tree guild, (UD) upland disturbance guild, (MS) mesic shrub guild, (MR) mesoriparian shrub and tree guild, and (US) understory shrub guild. Rooting depth and height at maturity are presented as box and quartile plots while categorical variables are presented as histograms of levels.

species with distinct life history strategy characteristics: (1) a long-lived, deeply-rooted, tall, shade tolerant, evergreen tree guild, (2) a rapidly growing, multi-stemmed, rhizomatous and thicket-forming, shrub guild, (3) a short-moderate stature, hydrophytic, multi-stemmed, thicketforming shrub guild, (4) an obligate riparian, medium-deeply rooted, vegetatively reproducing, alluvial substrate preferring, shrub and tree guild, and (5) a short-statured, shade-tolerant, water stress and flooding intolerant understory shrub guild (Table 3, Figs. 2 and 3). Guilds were given abbreviated names for simplicity of presentation: (1) evergreen tree, (2) upland disturbance, (3) mesic shrub, (4) mesoriparian shrub and tree, and (5) understory shrub (Table 3). The clustered guilds and their representative species separated based on their component functional attributes. This was apparent in the cluster dendrogram, summaries of guilds' functional attributes, and PCoA plot of species, and guild by functional attributes (Figs. 2 and 4; Appendices A-C). Morphological attribute composition differed significantly between guilds (PERMANOVA pseudo $F=8.79, P<0.001$ ). Species height at maturity and rooting depth were the two strongest drivers of the species by life history attribute (guild) ordination, followed by leaf retention, moisture use, growth form, growth rate, fire tolerance, vegetative spread rate, lifespan, bloom period, resprouting ability, drought tolerance and live-staking (Figs. 3 and 4; Appendix B). Life form, resource use, persistence and growth traits were more reflective of guild differences than species' reproductive duration and timing.

\section{Environmental gradients and guild distributions}

The five riparian guilds occurred in 32 different combinations of assemblages at the 703 study reaches (Fig, 5; Appendix E). A three-dimensional NMDS ordination solution of guild assem- 


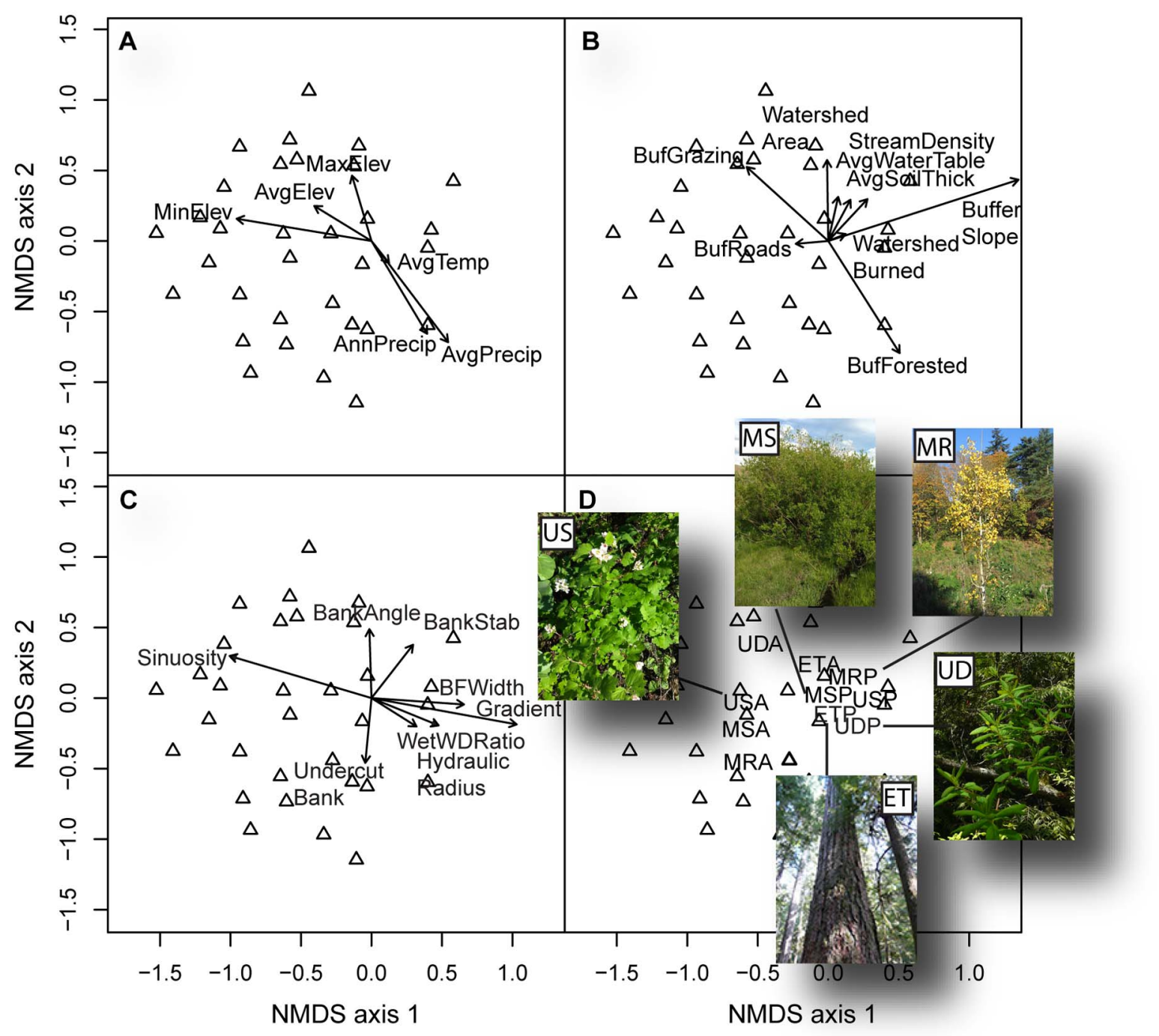

Fig. 5. Fitting of environmental vectors to the final nonmetric multi-dimensional scaling (NMDS) solution for trait assemblages at each reach showed that landscape (A), watershed and stream buffer (B) and stream (C) scale environmental filters were all correlated to guild assemblage composition. The presence and absence of individual guilds (D) illustrate how the presence and absence of each individual guild corresponded to guild assemblages at each reach. Abbreviations for environmental factors and guild vectors correspond to those found in tables two and three. For panel (D), MRA would indicate the absence of the mesoriparian guild while UDP would indicate the presence of the upland disturbance guild. Points in the NMDS ordination reflect the 32 combinations of guild presence and absence observed at the 703 study reaches. Darker points reflect more frequently occurring guild assemblages than lighter points

blages converged after 17 tries (principal components rotation; Euclidean distance; stress = $0.047, P=0.009)$. The combinations of guilds that assembled at each reach and individual guilds were strongly correlated to multiple environmental gradients (Fig. 5, Table 4; Appendices C and D). Buffer slope, reach elevation, sinuosity, stream gradient, buffer forest cover, and average and annual precipitation were most strongly correlated to the guild assemblage ordination solution (Fig. 5A-C; Appendix D). The guild assemblages within the NMDS ordination space 
Table 4. Generalized linear models for the presence and absence of each habitat guild. Parameters in boldface were significant in the final model. Models were selected with an information theoretic approach, iteratively comparing model AIC and log-likelihood as the variables with the weakest hypothesized relationships with guild presence/absence were removed. Pseudo $R^{2}$ are reported using the Cragg and Uhler (1970) and maximum likelihood methods. Model AIC, $\triangle \mathrm{AIC}$, log-likelihood alternative models are presented in Appendix E. See Table 3 for explanations of the short guild names.

\begin{tabular}{|c|c|c|c|c|c|}
\hline \multirow[b]{2}{*}{ Short guild name } & \multicolumn{3}{|c|}{ Final model terms } & \multicolumn{2}{|c|}{ Pseudo $R^{2}$} \\
\hline & Variable scale and terms & Estimate & SE & Cragg-Uhler & $\begin{array}{l}\text { Maximum } \\
\text { likelihood }\end{array}$ \\
\hline \multirow[t]{20}{*}{ A) Evergreen tree guild } & & & & 0.42 & 0.28 \\
\hline & Landscape & & & & \\
\hline & AvgTemp & -0.10 & 0.07 & & \\
\hline & AnnPrecip & 1.04 & 0.44 & & \\
\hline & Watershed & & & & \\
\hline & WatershedArea & -0.01 & 0.00 & & \\
\hline & AvgWaterTable & -0.97 & 0.42 & & \\
\hline & WatershedBurned & -0.01 & 0.00 & & \\
\hline & Buffer & & & & \\
\hline & BufForested & 0.06 & 0.01 & & \\
\hline & BufRoads & 0.17 & 0.10 & & \\
\hline & BufSlope & -0.05 & 0.01 & & \\
\hline & Stream & & & & \\
\hline & WetWDRatio & 0.03 & 0.01 & & \\
\hline & Sinuosity & -0.95 & 0.40 & & \\
\hline & Gradient & 0.18 & 0.11 & & \\
\hline & Biotic & & & & \\
\hline & UD & 0.61 & 0.24 & & \\
\hline & US & 0.88 & 0.27 & & \\
\hline & MR & -0.51 & 0.30 & & \\
\hline \multirow[t]{18}{*}{ B) Upland disturbance shrub guild } & & & & 0.23 & 0.16 \\
\hline & Landscape & & & & \\
\hline & AvgTemp & 0.11 & 0.05 & & \\
\hline & Watershed & & & & \\
\hline & WatershedArea & -0.00 & 0.00 & & \\
\hline & AvgWaterTable & -0.83 & 0.35 & & \\
\hline & Buffer & & & & \\
\hline & BufForested & 0.01 & 0.00 & & \\
\hline & BufSlope & -0.10 & 0.05 & & \\
\hline & Stream & & & & \\
\hline & BankAngle & -0.05 & 0.02 & & \\
\hline & BfWidth & 0.20 & 0.05 & & \\
\hline & WetWDRatio & 0.02 & 0.01 & & \\
\hline & Gradient & 0.40 & 0.10 & & \\
\hline & BufSlope:BankAngle & 0.00 & 0.00 & & \\
\hline & BfWidth:WetWDRatio & -0.00 & 0.00 & & \\
\hline & Biotic & & & & \\
\hline & ET & 0.57 & 0.23 & & \\
\hline \multirow{19}{*}{ C) Mesic shrub guild } & & & & 0.31 & 0.15 \\
\hline & Landscape & & & & \\
\hline & AvgTemp & -0.39 & 0.14 & & \\
\hline & AnnPrecip & -0.80 & 0.56 & & \\
\hline & MinElev & -0.00 & 0.00 & & \\
\hline & Watershed & & & & \\
\hline & WatershedArea & -0.00 & 0.00 & & \\
\hline & Buffer & & & & \\
\hline & BufSlope & 0.28 & 0.08 & & \\
\hline & Stream & & & & \\
\hline & BankAngle & 0.04 & 0.08 & & \\
\hline & BfWidth & 0.17 & 0.08 & & \\
\hline & WetWDRatio & -0.00 & 0.02 & & \\
\hline & Sinuosity & -0.56 & 0.34 & & \\
\hline & BfWidth:WetWDRatio & -0.00 & 0.00 & & \\
\hline & BufSlope:BankAngle & -0.00 & 0.00 & & \\
\hline & Biotic & & & & \\
\hline & US & 0.63 & 0.31 & & \\
\hline & MR & 0.74 & 0.31 & & \\
\hline
\end{tabular}


Table 4. Continued.

\begin{tabular}{|c|c|c|c|c|c|}
\hline \multirow[b]{2}{*}{ Short guild name } & \multicolumn{3}{|c|}{ Final model terms } & \multicolumn{2}{|c|}{ Pseudo $R^{2}$} \\
\hline & Variable scale and terms & Estimate & $\mathrm{SE}$ & Cragg-Uhler & $\begin{array}{l}\text { Maximum } \\
\text { likelihood }\end{array}$ \\
\hline \multirow{2}{*}{\multicolumn{4}{|c|}{ D) Mesoriparian shrub and tree guild }} & 0.26 & 0.17 \\
\hline & & & & & \\
\hline & AvgTemp & -0.43 & 0.10 & & \\
\hline & AnnPrecip & -0.66 & 0.39 & & \\
\hline & MinElev & -0.00 & 0.00 & & \\
\hline & Watershed & & & & \\
\hline & AvgSoilThick & 1.73 & 0.92 & & \\
\hline & Buffer & & & & \\
\hline & BufGrazing & 0.01 & 0.00 & & \\
\hline & BufRoads & 0.12 & 0.08 & & \\
\hline & BufSlope & 0.05 & 0.01 & & \\
\hline & Stream & & & & \\
\hline & BfWidth & 0.12 & 0.04 & & \\
\hline & Gradient & 0.18 & 0.09 & & \\
\hline & Biotic & & & & \\
\hline & ET & -0.51 & 0.26 & & \\
\hline & MS & 0.67 & 0.31 & & \\
\hline & US & 0.68 & 0.25 & & \\
\hline \multirow[t]{19}{*}{ E) Understory shrub guild } & & & & 0.33 & 0.21 \\
\hline & Landscape & & & & \\
\hline & AvgTemp & -0.23 & 0.11 & & \\
\hline & AnnPrecip & -4.12 & 1.44 & & \\
\hline & MinElev & -0.01 & 0.00 & & \\
\hline & AnnPrecip:Elev & 0.00 & 0.00 & & \\
\hline & Watershed & & & & \\
\hline & WatershedArea & -0.00 & 0.00 & & \\
\hline & Buffer & & & & \\
\hline & BufForested & -0.01 & 0.01 & & \\
\hline & BufRoads & 0.16 & 0.10 & & \\
\hline & BufSlope & 0.04 & 0.01 & & \\
\hline & Stream & & & & \\
\hline & BankAngle & -0.01 & 0.01 & & \\
\hline & Gradient & 0.48 & 0.12 & & \\
\hline & Biotic & & & & \\
\hline & ET & 0.87 & 0.27 & & \\
\hline & MS & 0.68 & 0.32 & & \\
\hline & MR & 0.83 & 0.25 & & \\
\hline
\end{tabular}

(Fig. 5D) and the fitting of individual guilds' presence and absence showed a clear and significant $(P<0.05$; PERMANOVA) separation between all five guilds. The individual upland disturbance, mesoriparian shrub and tree, and understory shrub guilds were most strongly correlated to guild assemblages in the final NMDS solution (Fig. 5; Appendix D). These correlations between guilds and guild assemblages were two to three-times stronger than any of the correlations between environmental filters and the ordination (Appendix D), indicating strong relationships between individual guilds and the assemblage of guilds at each reach.

Environmental filters and riparian guild coexistence

The presence and absence of individual ripar- ian guilds corresponded to many of the same environmental filters that correlated to guild assemblages in the NMDS ordination (Table 4). Generalized linear models (GLMs) and conditional inference trees (CITs) showed that for most guilds, in addition to environmental filtering effects from hydrologic and channel form attributes, the presence and absence of other guilds were significant predictors of guild presence and absence (Table 4). The final evergreen tree guild GLM showed that hydrologic variables, watershed area and average water table depth, and the channel-form variables, sinuosity and buffer slope, were negatively correlated to evergreen guild presence. Annual precipitation, wetted width-depth ratio, buffer forest cover and the presence of the upland disturbance and under- 
story shrub guilds were positively correlated to evergreen tree guild presence (Table 4). The evergreen tree guild's CIT confirmed that multiscale environmental filters and the presence of the upland disturbance guild were strong predictors of the evergreen tree guild's presence (Fig. $6 ; 82.2 \%$ correctly classified).

The final GLM for the upland disturbance guild showed that channel form variables were the most important filters related to guild presence. The model showed positive relationships between guild presence and buffer forest cover, average watershed temperature, bankfull width and gradient, and the buffer slope-bank angle interaction and negative relationships with bank angle, water table depth, and the bankfull width-wetted width depth ratio interaction. Presence of the evergreen tree guild was also positively correlated to upland disturbance guild presence in the GLM (Table 4; Appendix D). The upland disturbance guild's CIT showed that the presence of the evergreen tree guild was a major predictor of upland disturbance guild presence behind buffer slope. The final CIT successfully predicted upland disturbance guild presence at $71.6 \%$ of reaches (Fig. 6).

The final mesic shrub guild model showed that this guild corresponded to multi-scale environmental filters and two other riparian guilds. Average temperature, elevation, and buffer slope-bank angle interaction were negatively correlated to guild presence, while buffer slope, bank angle, bankfull width and the mesoriparian shrub and tree and understory guilds' presence positively correlated to this guild. The mesic shrub guild's CIT was solely comprised of the understory shrub and mesoriparian shrub and tree guilds' presence and absence. This model correctly predicted mesic shrub guild presence at $89.9 \%$ of reaches, but failed to successfully predict any absences and did not show more predictive power than random chance $(\mathrm{Kappa}=$ $0 ; \mathrm{Z}=0 ; P=0.5$ ).

The understory shrub guild was inversely correlated to average temperature, annual precipitation, minimum elevation, buffer forest cover and bank angle, predominantly landscape scale environmental filters, within its final GLM. This guild was positively correlated to the presence of all other guilds, except the upland disturbance guild, which was not included in the final GLM. Gradient and buffer slope were also positively correlated to the presence of this guild indicating a preference toward steeper streams and riparian areas. The presence and absence of the mesoriparian shrub and tree guild was significant in the CIT modeling of the understory shrub guild's distribution (Fig. 6). The final understory guild CIT successfully predicted guild presence and absence at $82.7 \%$ of reaches.

The mesoriparian shrub and tree guild was positively related to the mesic shrub and understory shrub guilds, but negatively associated with the evergreen tree guild. This guild was also negatively related to temperature and elevation and positively related to bankfull width, buffer slope, and grazing frequency in the buffer. The CIT model for the mesoriparian shrub and tree guild showed that in less steeply sloped reaches the mesic shrub and understory shrub guilds corresponded to mesoriparian shrub and tree guild presence (Fig. 6). This CIT correctly classified $78.2 \%$ of reaches.

\section{DISCUSSION}

We identified riparian plant guilds based on component species' distinctive life history strategies that reflect each guild's resource use, reproduction, persistence, and growth in the riparian environment. Specific characteristics that differentiated guilds were those that allowed guilds to tolerate flooding disturbance, acquire soil moisture and nutrition, and reproduce while coexisting with guilds of different life history strategies. Distinct life history strategies were tied to species' canopy height and root depth that allow for persistence and growth in competitive aboveground and belowground environments. Species moisture use and drought tolerance, commonly limiting factors in arid and semi-arid rivers (Shafroth et al. 2000, 2002, Horton et al. 2001), were important in differentiating guilds' with adaptations to fluvial and wetland environments (e.g., mesic shrub, mesoriparian shrub and tree) from guilds adapted to stressors like fire or herbivory (e.g., upland disturbance). Resprouting potential, vegetative spread, and live-staking capabilities, common adaptations to the riparian environment where species are buried, washed away or broken off by floods (Catford and Jansson 2014), differentiated the mesoriparian 


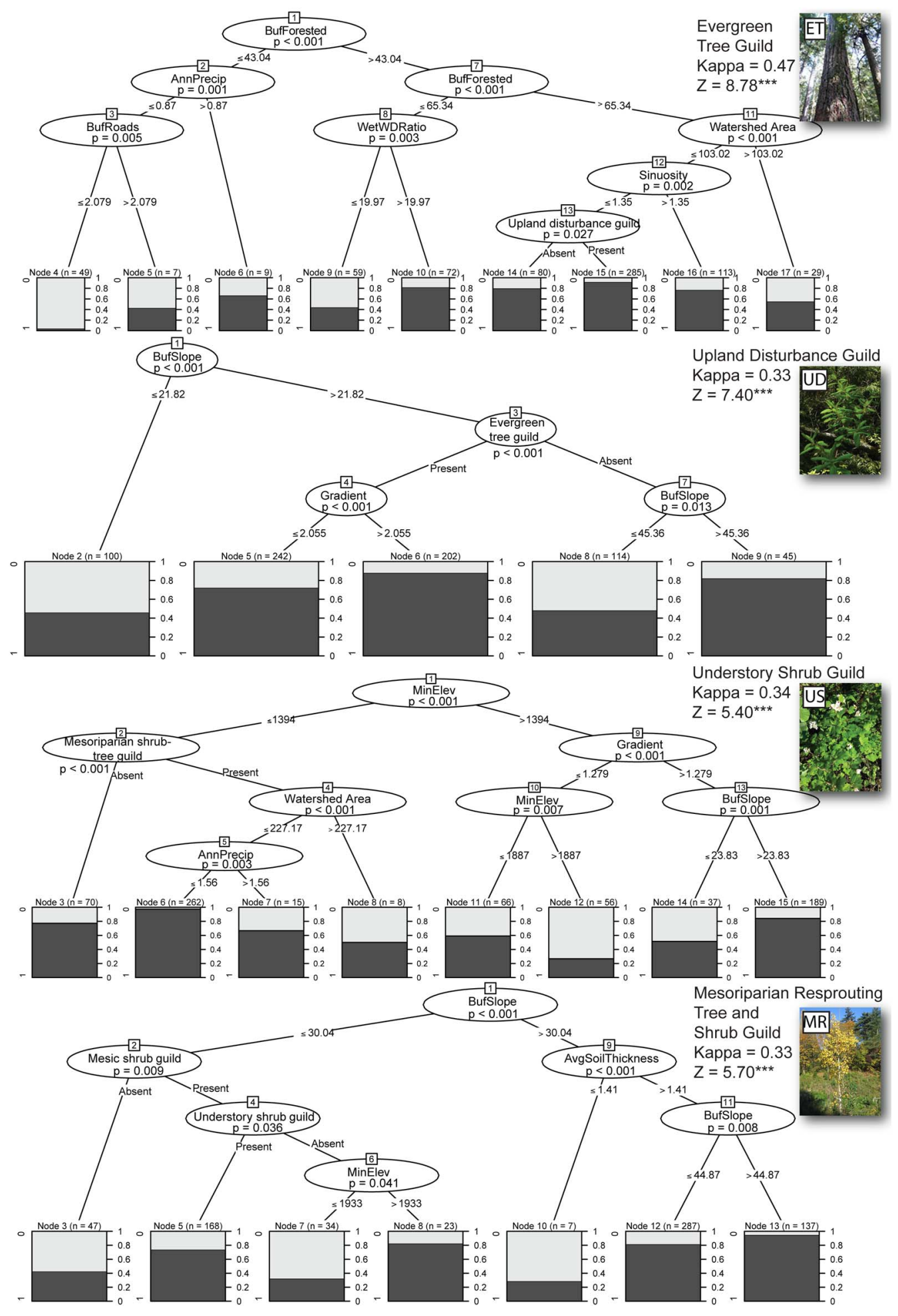

Fig. 6. Significant conditional inference trees (CITs) for four of the five riparian guilds showed that guild presence and absence are predicted by both environmental filters and the presence and absence of complementary functional guilds. The mesic shrub guild's final CIT was not a better predictor of guild presence or absence than random chance and is not presented here. 
and mesic shrub guilds from the more upland evergreen tree, upland disturbance, and understory guilds. Shade and drought tolerance, upland forest stressors that limit species distributions, differentiated the understory shrub and upland disturbance guilds from more hydrophytic guilds and the larger-statured evergreen tree guild.

Riparian functional guilds' distributions affirm that life-history strategies are selected for by multiple environmental filters (selective pressures) that are reflective of particular process domains (Montgomery 1999), such as hydrogeomorphic processes, local disturbance, and climate patterns that vary across large watersheds. For example, stream width, gradient, and sinuosity were predictors of multiple guilds, suggesting that hydrogeomorphic processes that shape channel form also eliminate or allow the persistence of local life history strategy diversity. This finding corresponds to research that showed wetland and riparian communities comprised of co-existing species were similarly correlated to multiple environmental filters (Lemly and Cooper 2011, Hough-Snee et al. 2014b) and that riparian forest regeneration strategies are tied to both environmental gradients and biotic interactions (Sarr et al. 2011). Functional guilds that respond to such gradients serve as good indicators of particular climatic and disturbance regimes. Such characterizations of typical suites of guilds for a particular process domain may provide sound reference states from which to understand departures from natural conditions and to set goals for restoration.

Individual guilds were often found either to be complementary to, or mutually exclusive with other guilds, suggesting that in some cases guilds' species differentially partition niches within similar environments. For example, the evergreen tree guild was positively associated with both the upland disturbance guild and the canopy understory guild, likely because these guilds acquire resources differently when coexisting in similar environments. The evergreen tree guild is unlikely to occupy disturbed forest edges suitable for the upland disturbance guild, and thus the two were often found together at a site, that is, the two guilds occupied different unique locations within a site, averting competitive exclusion. The understory shrub guild is positively associated with the evergreen tree guild because the tall, mature overstory trees provide suitable habitat for the shade-tolerant understory guild. The evergreen tree, upland disturbance and understory shrub guilds' rooting depths differ enough to suggest that each guild acquires soil resources independently within the soil profile.

Previous work identifying riparian guilds has focused on guild relationships to flow modification within a single stream network (e.g., Bejarano et al. 2011, 2012). We build upon these efforts by considering riparian functional plant diversity across large watersheds with diverse climatic and hydrogeomorphic settings, and disturbance regimes. We used extensive vegetation and stream monitoring data to show that the riparian guild concept can and should be extended to landscapes with diverse physiographic and bioclimatic settings such as the Columbia and Missouri River basins. For example, we showed that riparian guilds were structured directly by channel-forming, flowrelated metrics, and that many guilds with upland life-history strategies were linked to upland disturbances and bioclimatic factors that influence species' broad environmental niches.

To extend the riparian guild concept as a tool for understanding how riparian communities are structured across landscapes, traits used in guilding should include those that respond to spatially and temporally relevant environmental filters, including multiple disturbances (flooding, wildfire, grazing) and limiting resources (soil moisture, nutrition, light). Whenever possible, these traits should represent species' multiple life history stages (dispersal, establishment, persistence) and size classes. For example, in low-order streams where riparia blend into uplands, traits that comprise versatile non-riparian life history strategies will be important in identifying distinct guilds. When appropriate, guild-based forecasts should also incorporate biotic interactions between guilds-especially when guilds consist of species that modify their environment and/or facilitate establishment of later successional guilds. Linking these distinct guilds to multiple environmental filters and process domains should improve understanding of how riparian communities may respond to future climate and disturbance regimes within and between stream 
reaches.

By extending the guild concept, our approach provides a basis for quantifying trait-based vegetation groups and community assembly, which can be used to model probable riparian vegetation outcomes in future disturbance and climate scenarios (Kominoski et al. 2013). The multi-scale approach used here shows utility across diverse landscapes where stream physical setting and local management (e.g., grazing and logging pressure) vary within large catchments, and regional-scale drivers such as climate and climate-induced flow alteration shape riparian plant guilds and guild assemblages. The riparian guild framework, as applied in this study, provides a powerful, flexible approach to identify and prioritize the responses of functional plant diversity to multiple environmental filters. Because riparian ecosystems will respond to multiple environmental stressors under future global change scenarios, managers should consider building guild models that account for both flow-related habitat creation or maintenance and disturbance regimes that will change under probable land-use, water management and climatic scenarios.

The utility of the riparian guild framework is developing rapidly and will improve as increased stream morphology, riparian vegetation, and measured plant trait data become available. The riparian vegetation data in this study are relatively coarse, using reach-level species presence without linking guild locations to hydraulics that differentiate landforms' hydrogeomorphic settings along a reach. Because riparian plants respond to micro-site differences in environmental parameters such as groundwater elevation, flood exceedance probability, and patchy soil nutrient availability, the utility of guilding will increase as fine-scale geomorphic and vegetation data are paired with specific landscape filters relevant to individual catchments. Thus, future research should, whenever possible, incorporate spatially explicit, reach-scale hydrogeomorphic diversity with broader bioclimatic data. Future research can also build guilds using measured plant trait data on individuals, incorporating phenotypic plasticity into functional riparian guilds. Using average or ordinal ecological trait values for guilding may render environmental filters too narrowly, missing sub-optimal trait levels that indicate reduced plant performance caused by water-table declines (Cooper and Merritt 2012) or human disturbance. This suboptimal performance in response to shifting local environmental conditions may be captured by trait plasticity information and measured trait data, building more informative guilds.

Riparian vegetation is structured by hydrogeomorphic processes operating at a hierarchy of scales (from watersheds to reaches), but also influences the operation of such processes through feedback mechanisms (Merritt 2013). For example, large wood accumulation alters local hydraulics and the subsequent deposition of sediment that forms islands that provide suitable germination sites for new riparian communities that stabilize the landform (Wohl 2013). Identification and modeling of key riparian guilds that influence hydrogeomorphic processes could help predict habitat changes in both aquatic and riparian habitats. If keystone guilds are predictors of specific habitat types (e.g., canopy bird habitat), this could provide information for predicting changes in aquatic and riparian habitat quality for endangered species (sensu Merritt and Bateman 2012). In watersheds like the Columbia, where endangered salmonid habitat conservation and restoration are national management priorities, the ability to predict habitat processes or habitat condition based on riparian guild dynamics could explicitly link riparian ecology to aquatic conservation (sensu Kominoski et al. 2011, Hough-Snee et al. 2014a).

The identification and modeling of riparian vegetation guilds and communities in explanatory capacities provides baseline information on the diversity of plant life history strategies that occur across landscapes. This baseline will be of increasing importance as land-use, water management, and climate change reshape many environmental filters. While understanding the relationships between riparian species, their component traits, and environmental filters is a fundamental question in riparian ecology, land and water-resource managers require informed hypotheses on how changes in environmental filters will change the ecosystems that they steward. Probabilistic, predictive modeling of trait-based plant guilds' responses to anthropogenic flow-regime modification, changes in climate, and anthropogenic and natural disturbance 
filters can provide these hypotheses. As thorough conceptual and empirical models enhance the understanding of how riparian ecosystems function and confer ecosystem services, they should be expeditiously employed to predict and forecast how riparian guilds, habitats, and ecosystem services may change in response to likely watershed management and global change scenarios.

\section{ACKNOWLEDGMENTS}

N. Hough-Snee, D. M. Merritt, and B. B. Roper conceptualized the project. N. Hough-Snee, B. G. Laub, A. L. Long, and L. L. Nackley assembled species and trait information and built a riparian guild database. N. Hough-Snee performed database work, statistical analyses, and created figures and tables. N. HoughSnee, B. G. Laub, D. M. Merritt, A. L. Long, L. L. Nackley, B. B. Roper, and J. M. Wheaton wrote the manuscript. We thank Martha Jensen, Wally MacFarlane, Rebecca Rossi, Alex Walker, Ryan Sponseller, and three anonymous reviewers for helpful comments on manuscript drafts, Nancy Huntly, Daniel Sarr, Mike Scott, and Julie Stromberg for meaningful discussions regarding riparian vegetation guilds, and USFS employees for data collection and stewardship. USFS Regions 1, 4, and 6, and BLM state field offices in Washington, Oregon, and Idaho funded data collection and management through the PACFISH/INFISH Biological Opinion EMP. N. Hough-Snee was supported in part by a Presidential Fellowship from Utah State University and STAR Fellowship Assistance Agreement number 91768201-0 awarded by the U.S. Environmental Protection Agency (EPA). This research has not been formally reviewed by the EPA. The views expressed herein are solely those of the authors. EPA does not endorse any products or commercial services mentioned in this publication.

\section{Literature Cited}

Anderson, M. J. 2001. A new method for nonparametric multivariate analysis of variance. Austral Ecology 26:32-46.

Bejarano, M. D., M. González del Tánago. D. G. de Jalón, M. Marchamalo, Á. Sordo-Ward, and J. Solana-Gutiérrez. 2012. Responses of riparian guilds to flow alterations in a Mediterranean stream. Journal of Vegetation Science 23:443-458.

Bejarano, M. D., C. Nilsson, M. González del Tánago, and M. Marchamalo. 2011. Responses of riparian trees and shrubs to flow regulation along a boreal stream in northern Sweden. Freshwater Biology 56:853-866.

ECOSPHERE www.esajournals.org
Bejarano, M. D., A. Sordo-Ward, M. Marchamalo, and M. González del Tánago. 2013. Geomorphological controls on vegetation responses to flow alterations in a Mediterranean stream. River Research and Applications 29:1237-1252.

Bendix, J., and C. R. Hupp. 2000. Hydrological and geomorphological impacts on riparian plant communities. Hydrological Processes 14:2977-2990.

Burgdorf, D. 2007. Plant species with rooting ability from live hardwood materials for use in soil bioengineering. Plant Materials Technical Note. USDA NRCS, East Lansing, Michigan, USA.

Cao, Y., C. P. Hawkins, J. Olson, and M. A. Kosterman. 2007. Modeling natural environmental gradients improves the accuracy and precision of diatombased indicators. Journal of the North American Benthological Society 26:566-585.

Catford, J. A., and R. Jansson. 2014. Drowned, buried and carried away: effects of plant traits on the distribution of native and alien species in riparian ecosystems. New Phytologist 204:19-36.

Cooke, H. A., and S. Zack. 2008. Influence of beaver dam density on riparian areas and riparian birds in shrubsteppe of Wyoming. Western North American Naturalist 68:365-373.

Cooper, D. J., and D. M. Merritt. 2012. Assessing the water needs of riparian and wetland vegetation in the western United States. General Technical Report 282. Rocky Mountain Research Station, Fort Collins, Colorado, USA.

Cragg, J. G., and R. S. Uhler. 1970. The demand for automobiles. Canadian Journal of Economics 3:386-406.

Dalldorf, K. N., S. R. Swanson, D. F. Kozlowski, K. M. Schmidt, R. S. Shane, and G. Fernandez. 2013. Influence of livestock grazing strategies on riparian response to wildfire in northern Nevada. Rangeland Ecology and Management 66:34-42.

De'ath, G., and K. E. Fabricius. 2000. Classification and regression trees: a powerful yet simple technique for ecological data analysis. Ecology 81:3178-3192.

Delong, M., and M. Brusven. 1994. Allochthonous input of organic matter from different riparian habitats of an agriculturally impacted stream. Environmental Management 18:59-71.

Díaz, S., M. Cabido, and F. Casanoves. 1998. Plant functional traits and environmental filters at a regional scale. Journal of Vegetation Science 9:113122.

Duckworth, J. C., M. Kent, and P. M. Ramsay. 2000. Plant functional types: an alternative to taxonomic plant community description in biogeography? Progress in Physical Geography 24:515-542.

Dunn, W. C., B. T. Milne, R. Mantilla, and V. K. Gupta. 2011. Scaling relations between riparian vegetation and stream order in the Whitewater River network, Kansas, USA. Landscape Ecology 26:983-997. 
Ekness, P., and T. Randhir. 2007. Effects of riparian areas, stream order, and land use disturbance on watershed-scale habitat potential: an ecohydrologic approach to policy. Journal of the American Water Resources Association 43:1468-1482.

Gower, J. C., and P. Legendre. 1986. Metric and Euclidean properties of dissimilarity coefficients. Journal of Classification 3:5-48.

Grime, J. P. 1977. Evidence for the existence of three primary strategies in plants and its relevance to ecological and evolutionary theory. American Naturalist 111:1169-1194.

Grime, J. P. 2001. Plant strategies, vegetation processes, and ecosystem properties. Wiley, New York, New York, USA.

Gurnell, A. 2014. Plants as river system engineers. Earth Surface Processes and Landforms 39:4-25.

Herbst, D. B., M. T. Bogan, S. K. Roll, and H. D. Safford. 2012. Effects of livestock exclusion on instream habitat and benthic invertebrate assemblages in montane streams. Freshwater Biology 57:204217.

Horton, J. L., T. E. Kolb, and S. C. Hart. 2001. Physiological response to groundwater depth varies among species and with river flow regulation. Ecological Applications 11:1046-1059.

Hothorn, T., K. Hornik, and A. Zeileis. 2006. Unbiased recursive partitioning: a conditional inference framework. Journal of Computational and Graphical Statistics 15:651-674.

Hough-Snee, N., A. Kasprak, B. B. Roper, and C. S. Meredith. 2014a. Direct and indirect drivers of instream wood in the interior Pacific Northwest, USA: decoupling climate, vegetation, disturbance, and geomorphic setting. Riparian Ecology and Conservation 2:14-34.

Hough-Snee, N., B. B. Roper, J. M. Wheaton, and R. L. Lokteff. 2014b. Riparian vegetation communities of the American Pacific Northwest are tied to multiscale environmental filters. River Research and Applications. http://dx.doi.org/10.1002/rra.2815

Hupp, C. R., and W. R. Osterkamp. 1996. Riparian vegetation and fluvial geomorphic processes. Geomorphology 14:277-295.

Huston, M., and T. Smith. 1987. Plant succession: life history and competition. American Naturalist 130:168-198.

Katz, G. L., J. C. Stromberg, and M. W. Denslow. 2009. Streamside herbaceous vegetation response to hydrologic restoration on the San Pedro River, Arizona. Ecohydrology 2:213-225.

Keddy, P. A. 1992. Assembly and response rules: two goals for predictive community ecology. Journal of Vegetation Science 3:157-164.

Kershner, J. L., E. K. Archer, M. Coles-Ritchie, E. R. Cowley, R. C. Henderson, K. Kratz, C. M. Quimby, D. L. Turner, L. C. Ulmer, and M. R. Vinson. 2004.
Guide to effective monitoring of aquatic and riparian resources. General Technical Report, 121st edition. USDA Forest Service Rocky Mountain Research Station, Logan, Utah, USA.

Kominoski, J. S., L. B. Marczak, and J. S. Richardson. 2011. Riparian forest composition affects stream litter decomposition despite similar microbial and invertebrate communities. Ecology 92:151-159.

Kominoski, J. S., et al. 2013. Forecasting functional implications of global changes in riparian plant communities. Frontiers in Ecology and the Environment 11:423-432.

Lemly, J. M., and D. J. Cooper. 2011. Multiscale factors control community and species distribution in mountain peatlands. Botany 89:689-713.

Lowe, W. H., and G. E. Likens. 2005. Moving headwater streams to the head of the class. BioScience 55:196.

McCune, B., and J. B. Grace. 2002. Analysis of ecological communities. MGM Software Design, Gleneden Beach, Oregon, USA.

Mcgill, B., B. Enquist, E. Weiher, and M. Westoby. 2006. Rebuilding community ecology from functional traits. Trends in Ecology and Evolution 21:178-185.

Merritt, D. M. 2013. Reciprocal relations between riparian vegetation, fluvial landforms, and channel processes. Pages 219-243 in J. F. Shroder, editor. Treatise on geomorphology. Elsevier, New York, New York, USA.

Merritt, D. M., and H. L. Bateman. 2012. Linking stream flow and groundwater to avian habitat in a desert riparian system. Ecological Applications 22:1973-1988.

Merritt, D. M., and D. J. Cooper. 2000. Riparian vegetation and channel change in response to river regulation: a comparative study of regulated and unregulated streams in the Green River Basin, USA. Regulated Rivers: Research and Management 16:543-564.

Merritt, D. M., M. L. Scott, N. L. Poff, G. T. Auble, and D. A. Lytle. 2009. Riparian vegetation-flow response guilds: a tool for determining environmental flows for riparian vegetation. Stream Notes October:1-8.

Merritt, D. M., M. L. Scott, N. L. Poff, G. T. Auble, and D. A. Lytle. 2010. Theory, methods and tools for determining environmental flows for riparian vegetation: riparian vegetation-flow response guilds. Freshwater Biology 55:206-225.

Merritt, D. M., and E. E. Wohl. 2006. Plant dispersal along rivers fragmented by dams. River Research and Applications 22:1-26.

Montgomery, D. R. 1999. Process domains and the river continuum. Journal of the American Water Resources Association 35:397-410.

Naiman, R. J., R. E. Bilby, and P. A. Bisson. 2000. Riparian ecology and management in the Pacific 
coastal rain forest. BioScience 50:996-1011.

NRCS [National Resources Conservation Service]. 2012. Web soil survey. http://websoilsurvey.nrcs. usda.gov/

Oksanen, J., F. G. Blanchet, R. Kindt, P. Legendre, P. R. Minchin, R. B. O'Hara, G. L. Simpson, P. Solymos, M. H. H. Stevens, and H. Wagner. 2013. vegan: community ecology package. http://vegan.r-forge. r-project.org/FAQ-vegan.html

Patten, D. T. 1998. Riparian ecosytems of semi-arid North America: diversity and human impacts. Wetlands 18:498-512.

PIBO EM [PACFISH/INFISH Biological Opinion Effectiveness Monitoring]. 2012a. PACFISH/INFISH Biological Opinion Effectiveness Monitoring Program for streams and riparian areas: 2012 sampling protocol for vegetation parameters. USDA Forest Service, Logan, Utah, USA.

PIBO EM [PACFISH/INFISH Biological Opinion Effectiveness Monitoring]. 2012b. PACFISH/INFISH Biological Opinion Effectiveness Monitoring Program for streams and riparian areas: 2012 sampling protocol for stream channel attributes. USDA Forest Service, Logan, Utah, USA.

Pollock, M. M., T. J. Beechie, M. Liermann, and R. E. Bigley. 2009. Stream temperature relationships to forest harvest in Western Washington. Journal of the American Water Resources Association 45:141156.

Reich, P. B. 2014. The world-wide "fast-slow" plant economics spectrum: a traits manifesto. Journal of Ecology 102:275-301.

Richardson, J. S., and R. J. Danehy. 2007. A synthesis of the ecology of headwater streams and their riparian zones in temperate forests. Forest Science 53:131-147.

Sarr, D. A., D. E. Hibbs, J. P. A. Shatford, and R. Momsen. 2011. Influences of life history, environmental gradients, and disturbance on riparian tree regeneration in western Oregon. Forest Ecology and Management 261:1241-1253.

Scott, M. L., S. K. Skagen, and M. F. Merigliano. 2003. Relating geomorphic change and grazing to avian communities in riparian forests. Conservation Biology 17:284-296.

Shafroth, P. B., J. C. Stromberg, and D. T. Patten. 2000. Woody riparian vegetation response to different alluvial water table regimes. Western North American Naturalist 60:66-76.

Shafroth, P. B., J. C. Stromberg, and D. T. Patten. 2002. Riparian vegetation response to altered disturbance and stress regimes. Ecological Applications 12:107123.

Stella, J. C., and J. J. Battles. 2010. How do riparian woody seedlings survive seasonal drought? Oecologia 164:579-590.

Stella, J. C., P. M. Rodríguez-González, S. Dufour, and J. Bendix. 2013. Riparian vegetation research in Mediterranean-climate regions: common patterns, ecological processes, and considerations for management. Hydrobiologia 719:291-315.

Stromberg, J. C., P. B. Shafroth, and A. F. Hazelton. 2012. Legacies of flood reduction on a dryland river. River Research and Applications 28:143-159.

USDA NRCS [Natural Resources Conservation Service]. 2010. The PLANTS database. http://plants. usda.gov

USGS. 2012. Landscape fire and resource management planning tools (LANDFIRE). http://www.landfire. gov

Viers, J. H., A. K. Fremier, R. A. Hutchinson, J. F. Quinn, J. H. Thorne, and M. G. Vaghti. 2012. Multiscale patterns of riparian plant diversity and implications for restoration. Restoration Ecology 20:160-169.

Whigham, D. F., C. M. Walker, R. S. King, and S. J. Baird. 2012. Multiple scales of influence on wetland vegetation associated with headwater streams in Alaska, USA. Wetlands 32:411-422.

Winward, A. H. 2000. Monitoring the vegetation resources in riparian areas. US Department of Agriculture, Forest Service, Rocky Mountain Research Station Ogden, Utah, USA.

Wohl, E. 2013. Floodplains and wood. Earth-Science Reviews 123:194-212.

\section{Supplemental Material}

\section{ECOLOGICAL ArCHIVES}

Appendices A-E are available online: http://dx.doi.org/10.1890/ES15-00064.1.sm 